\title{
Stability of Strawberry Genotypes in the Annual Hill Cultural System
}

\author{
Craig K. Chandler, Peter J. Stoffella', Earl E. Albregts, and \\ Charles M. Howard \\ Agricultural Research and Education Center, Institute of Food and \\ Agricultural Sciences, University of Florida, Dover, FL 33527
}

Additional index words Fragaria $\times$ ananassa, genotype $\times$ environment interaction, linear regression analysis, adaptability

Abstract. Plants of 'Selva', 'Pajaro', and three Univ. of Florida strawberry (Fragaria $\times$ ananassa Duch.) selections were grown near Dover, Fla., for five seasons using the annual hill cultural system. Genotype $x$ environment interactions were significant for both marketable yield and fruit weight; therefore, stability analyses were performed.

None of the genotypes had consistently high marketable yield, but one of the selections, FL M-1350, had relatively large and stable average fruit size. A genotype was desirable if it had a mean yield (or fruit weight) above the grand mean of all five genotypes, a regression coefficient $\leq 1$, and a nonsignificant deviation from regression.

Strawberry production in Florida is concentrated in the west-central region of the state, between Tampa and Lakeland, on $\approx 2000$ ha (Freie and Young, 1990). A mild and sunny climate with relatively few damaging freezes makes this area well suited for winter strawberry production. Strawberry plants are planted annually in October on raised beds that have been fumigated and covered with black polyethylene mulch. The harvest season usually starts in December, with heaviest production in January through March.

Recently, west-central Florida growers mostly have planted the California cultivars Selva and Pajaro to satisfy market demands. 'Selva' is prized for its long shelf life and its ability to produce some fruit in November and early December. 'Pajaro' is popular because its fruit is generally firm, attractive, and flavorful. These cultivars have been relatively low-yielding in Florida (Chandler et al., 1989). Contributing to the low yield of 'Pajaro' is its extreme susceptibility to anthracnose fruit rot incited by Colletotrichum spp. (Howard et al., 1985), the most serious disease affecting strawberries in Florida. Anthracnose fruit rot and most other fruit rots affecting strawberries in Florida are favored by warm, rainy weather. Average monthly temperatures and rainfall amount during the strawberry growing season can be variable from year to year (Table 1), contributing to variability in the incidence of disease.

A major goal of the Univ. of Florida's strawberry breeding program is to identify

Received for publication 18 Mar. 1991. Florida Agricultural Experiment Station Journal Series no. R-01274. The cost of publishing this paper was defrayed in part by the payment of page charges. Under postal regulations. this paper therefore mus be hereby marked advertisement solely to indicate this fact.

Professor of Vegetable Crops, Agricultural Research and Education Center, IFAS, Univ. of Florida, Fort Pierce, FL 34954 genotypes that are large-fruited and highyielding regardless of environmental conditions. Published yield stability studies on strawberry appear to be limited to strawberries grown in matted rows in the north-central region of the United States (Chandler and Hill, 1988; Hancock, 1985; Hanson, 1989; Pritts and Luby, 1990). We, therefore, assessed yield and fruit size stability of 'Selva', 'Pajaro', and three Univ. of Florida selections grown in Florida using the annual hill cultural system.

Description of trials. Plants of 'Selva', 'Pajaro', and the Univ. of Florida selections, FL 79-1126, FL 81-1350, and FL 82-1452, were grown at the Agricultural Research and Education Center, Dover, Fla., during the 1985-86 through 1989-90 seasons. The research center is located in the heart of the commercial strawberry-growing area, $\approx 21$ $\mathrm{km}$ east-northeast of Tampa Bay, at $28^{\circ} \mathrm{N}$ lat. and $23 \mathrm{~m}$ above sea level. The soil type is a Seffner fine sand (sandy, siliceous, hyperthermic Quartzipsammentic Haplumbrepts)

Single-crown transplants were set each October through black polyethylene mulch on standard (Albregts and Howard, 1984) two-row raised beds that had been fumigated with $336 \mathrm{~kg}$ of MC98-2 (98\% methyl bromide, $2 \%$ chloropicrin) per bedded hectare and fertilized with $10 \mathrm{~N}-4 \mathrm{P}-10 \mathrm{~K}$ at a rate of $2.2 \mathrm{t} \cdot \mathrm{ha}^{-1}$ before planting. One-fourth of the fertilizer was broadcast before bed preparation; the remainder was banded 2.5 to 5.0 $\mathrm{cm}$ deep in the bed center. One-half of the $\mathrm{N}$ was applied in the form of sulfur-coated urea; the other half in the form of ammonium nitrate. Plants were spaced $30 \mathrm{~cm}$ apart in the row, with $30 \mathrm{~cm}$ between rows. Five plots of each clone were planted in a randomized complete block design. Each plot contained 14 plants. Pesticides and water (sprinkler irrigation) were applied as needed. Fruit were harvested, graded, counted, and weighed twice a week during January through March.

Statistical analysis. A combined analysis 
Table 1. Mean temperature $\left({ }^{\circ} \mathrm{C}\right)$ and rainfall $(\mathrm{mm})$ at the Agricultural Research and Education Center, Dover, Fla.

\begin{tabular}{lccccc}
\hline \hline & \multicolumn{5}{c}{ Season } \\
\cline { 2 - 6 } Month & $1985-86$ & $1986-87$ & $1987-88$ & $1988-89$ & $1989-90$ \\
\hline October & & & & & \\
$\quad$ Temperature & 26 & 24 & 21 & 22 & 23 \\
$\quad$ Rainfall & 30 & 210 & 80 & 260 & 60 \\
$\begin{array}{l}\text { November } \\
\text { Temperature }\end{array}$ & 22 & 24 & 20 & 21 & 20 \\
$\quad$ Rainfall & 60 & 40 & 110 & 180 & 60 \\
$\begin{array}{l}\text { December } \\
\text { Temperature }\end{array}$ & 14 & 19 & 17 & 16 & 13 \\
$\quad$ Rainfall & 30 & 80 & 10 & 30 & 140 \\
January & & & & & \\
$\quad$ Temperature & 15 & 15 & 14 & 19 & 19 \\
$\quad$ Rainfall & 80 & 100 & 100 & 80 & 20 \\
February & & & & & \\
$\quad$ Temperature & 18 & 17 & 14 & 18 & 20 \\
$\quad$ Rainfall & 50 & 70 & 50 & 10 & 130 \\
March & 18 & 19 & 18 & 21 & 20 \\
$\quad$ Temperature & 18 & 350 & 170 & 40 & 30 \\
$\quad$ Rainfall & 120 & & & & \\
\hline
\end{tabular}

Table 2. Mean squares from combined analysis of variance for marketable strawberry fruit yields and fruit weight.

\begin{tabular}{lccc}
\hline \hline $\begin{array}{l}\text { Source of } \\
\text { variation }\end{array}$ & df & $\begin{array}{c}\text { Marketable yield } \\
\left(\mathrm{t} \cdot \mathrm{ha}^{-1}\right)\end{array}$ & $\begin{array}{c}\text { Fruit wt } \\
(\mathrm{g})\end{array}$ \\
\hline Environments (Env) & 4 & $185.5^{* *}$ & 6.4 \\
Replication/Env & 20 & 12.5 & 3.4 \\
Genotype (Gen) & 4 & $744.9^{* *}$ & 29.1 \\
Env $\times$ Gen & 16 & $51.5^{* *}$ & $4.3^{*}$ \\
Experimental error & 80 & 9.4 & 2.0 \\
\hline
\end{tabular}

*,**Significant $\mathrm{F}$ test at $P=0.05$ and 0.01 , respectively.

Table 3. Stability estimates for marketable fruit yield of several strawberry genotypes grown at Dover, Fla.

\begin{tabular}{lcccc} 
Fla. & $\begin{array}{c}\text { Marketable } \\
\text { fruit yield } \\
\left(\mathrm{t} \cdot \mathrm{ha}^{-1}\right)\end{array}$ & $b_{1}$ & $\begin{array}{c}\text { Deviation from } \\
\text { regression } \\
\text { (mean square) }\end{array}$ & $\mathrm{CV}$ \\
Genotype & 13.4 & 0.28 & $42.3^{*}$ & 30.2 \\
\hline Selva & 15.2 & 1.68 & 0.7 & 15.2 \\
Pajaro & 24.9 & 1.53 & $12.5^{*}$ & 17.4 \\
FL 79-1126 & 25.3 & 1.76 & 40.9 & 23.8 \\
FL 81-1350 & 19.2 & -0.25 & 9.7 & 18.3 \\
FL 82-1452 & 19.6 & 1.00 & & 15.7 \\
\hline
\end{tabular}

*Significant $\mathrm{F}$ test at $P=0.05$.

Table 4. Stability estimates for fruit weight of several strawberry genotypes grown at Dover, Fla.

\begin{tabular}{lcccr}
\hline \hline Genotype & $\begin{array}{c}\text { Fruit wt } \\
(\mathrm{g})\end{array}$ & \multicolumn{1}{c}{$\begin{array}{c}\text { Deviation from } \\
\text { regression } \\
\text { (mean square) }\end{array}$} & \multicolumn{1}{c}{ CV } \\
\hline Selva & 15.4 & -0.30 & 2.43 & 8.85 \\
Pajaro & 16.9 & 2.58 & 0.42 & 10.17 \\
FL 79-1126 & 15.9 & 0.11 & $3.62^{* *}$ & 5.40 \\
FL 81-1350 & 17.4 & 0.55 & 2.38 & 5.74 \\
FL 82-1452 & 18.0 & 2.03 & 3.56 & 14.52 \\
X & 16.7 & 1.00 & & 8.40 \\
\hline
\end{tabular}

** Significant $\mathrm{F}$ test at $P=0.01$.

of variance (ANOVA) across years was performed with environments (years) and genotypes considered fixed effects. Appropriate error terms were used to test significance among environments, genotypes, and environment $\times$ genotype interactions. The marketable yield and fruit weight stability of each genotype was assessed using two indices: coefficient of variability $(\mathrm{cv})$ and linear regression analysis (Eberhart and Russell, 1966; Finlay and Wilkinson, 1963). The de- viation from linear regression mean squares were tested using the pooled error mean square. Genotypes with a mean yield above the grand mean yield (mean of all five genotypes) and $b_{l}>1$ were considered unstable and only adapted to favorable environments. Genotypes with a mean yield below the grand mean and $b_{1}<1$ were considered stable but low-yielding. Genotypes with a mean yield below the grand mean and $b_{1}>1$ were considered unstable and low-yielding. We con- sidered a genotype desirable when it had a mean yield (or fruit weight) above the grand mean, $b_{l} \leq 1$, and a nonsignificant deviation from regression.

Main effects of environments (years) and genotypes from the combined ANOVA were significant for marketable yield (Table 2). The mean yearly marketable yield ranged from 16.4 to $23.3 \mathrm{t} \cdot \mathrm{ha}^{-1}$, a $42 \%$ increase from the worst year to the best year, suggesting that both favorable and unfavorable environments had occurred during the evaluation period. Genotype $\times$ environment interactions were significant for both marketable yield and fruit weight (Table 2), indicating that stability analyses were appropriate.

The stability analyses showed that none of the genotypes had consistently high marketable yields (Table 3). 'Selva' was stable but low-yielding, while 'Pajaro' was both unstable and low-yielding. The Florida-bred genotypes had a higher average yield than the California cultivars but were unstable. FL 79-1126 and FL 81-1350, with $b_{l}>1$, can only be considered adapted to favorable environments, while FL 82-1452, with $b_{1}<$ 0 , is an anomaly.

Only FL 81-1350 had a mean average fruit weight above the grand mean, $b_{l}<1$, and a nonsignificant deviation from regression (Table 4). A below-average cv is further proof of FL 81-1350's fruit size stability. However, fruit of this selection bruise easily and, therefore, are not suitable for long-distance shipping. FL 82-1452 had impressive average fruit weight, but, like 'Pajaro', its average fruit weight varied considerably from year to year.

Phenotypically stable cultivars would be of great benefit to the Florida strawberry industry. The use of such cultivars might result in a more stable market; growers could produce predictable supplies and pack a consistent product. 'Selva' and 'Pajaro', the current industry standards, cannot be considered phenotypically stable based on the results of this study, but are grown extensively because they have acceptable fruit quality and, in the case of 'Selva', can produce some fruit in November and early December.

What are the prospects of developing phenotypically stable strawberry cultivars for west-central Florida? The heritability of yield and fruit weight stability has not been investigated in strawberry, but is probably low based on work done in other crops (Becker and Leon, 1988). Increasing the stability of yield may be possible, however, by developing genotypes with greater fruit rot resistance. Such clones likely would be less vulnerable to periods of rainy weather and high humidity. FL 79-1126 is highly resistant to anthracnose fruit rot, but susceptible to gray mold (incited by Botrytis cinerea Pers. ex Fr.) (C.M.H., unpublished data). Despite the difficulty that may be encountered in generating stable genotypes, the evaluation of existing and future genotypes for stability will be relatively easy. Stability estimates can be calculated routinely using powerful statistical software packages such as SAS (SAS Institute, 1979). 
An alternative to the development of more stable genotypes is the modification of cultural and pest management practices so that genotypes like FL 79-1126, which are adapted only to favorable environments, are less likely to be exposed to unfavorable environments.

\section{Literature Cited}

Albregts, E.E. and C.M. Howard. 1984. Strawberry production in Florida. Florida Agr. Expt. Sta. Res. Bul. 841.

Becker, H.C. and J. Leon. 1988. Stability analysis in plant breeding. Plant Breeding 101:1-23. Chandler, C.K. and R.G. Hill. 1988. Yield and production stability of strawberry cultivars grown at the Ohio Agricultural Research and Dvelopment Center, Wooster, 1952-1987. Fruit Var. J. 42:139-142.

Chandler, C.K., E.E. Albregts, and CM. Howard. 1989. Evaluation of strawberry cultivars and selections at Dover, Florida 1986-1988. Adv. Strawberry Prod. 8:19-22.

Eberhart, S.A. and W.A. Russell. 1966. Stability parameters for comparing varieties. Crop Sci. 6:36-40.

Finlay, K.W. and G.N. Wilkinson. 1963. The analysis of adaptation in a plant-breeding proanalysis of adaptation in a plant-breeding pro-

Freie, R.L. and H.V. Young. 1990. Florida ag- ricultural statistics, vegetable summary, 1988 1989. Florida Agr. Stat. Serv.. Orlando. Fla. Hancock, J.F. 1985. Yield stability in 10 cultivars of strawberry. Fruit Var. J. 39:18-21

Hanson, E.J. 1989. Performance of strawberry cultivars in the north central region of the United States. Fruit Var. J. 43:151-154.

Howard, C.M., A.J. Overman, J.F. Price, an E.E. Albregts. 1985. Diseases, nematodes. mites, and insects affecting strawberries in Florida. Florida Agr. Expt. Sta. Res. Bul. 857

Pritts, M. and J. Ruby.-1990. Stability indices for horticultural crops. HortScience 25:740-745. hAS Intiture 1979. SAS user's 25.740-745. 1979 ed. SAS Inst., Inc., Cary, N.C. 